\title{
Small mammals (Didelphimorphia, Rodentia and Chiroptera) from Pampean Region, Argentina
}

\author{
Fernando J. Fernández , Fabricio Idoeta, César García-Esponda, Joaquín D. Carrera, Germán J. \\ Moreira, Fernando Ballejo and Luciano J. M. De Santis \\ Universidad Nacional de La Plata, Facultad de Ciencias Naturales y Museo, Cátedra de Anatomía Comparada. Calle 64 s/n (entre diag. 113 y calle \\ 120). CP 1900. La Plata, Buenos Aires, Argentina. \\ * Corresponding author. E-mail: fernandezf77@yahoo.com.ar
}

\begin{abstract}
We studied small mammal assemblages recovered from owl pellets collected at 11 locations throughout the Argentina's Pampean Region. We identified 21 species, including two marsupials, one bat, and 18 rodents. From the analysis of this dataset, we could distinguish three main groups of small mammals that currently inhabit the Pampean Region: 1) a group of taxa related to Pampean agroecosystems (Calomys spp., Akodon azarae, and Oligoryzomys flavescens); 2) a group of Brazilian species (Cavia aperea, Oxymycterus rufus, Necromys lasiurus, Necromys obscurus, Holochilus brasiliensis, and Monodelphis dimidiata); and 3) a group including species from Patagonia, Espinal and Monte phytogeographic provinces (Microcavia australis, Oligoryzomys longicaudatus, Eligmodontia typus, Graomys griseoflavus, and Akodon molinae). In addition, we documented the first record of a species of the large-bodied group of Calomys in Buenos Aires province, expanding its distribution ca. $420 \mathrm{~km}$ southward.
\end{abstract}

\section{INTRODUCTION}

The Pampean Region is a large ecosystem of grasslands plains located in Central-Eastern Argentina, including southern Córdoba and Santa Fe provinces, and most of La Pampa and Buenos Aires provinces (León 1991). This region is ecologically interesting, since it comprises three different phytogeographic provinces: Pampa, Espinal and Monte (Cabrera 1976). From a zoogeographic perspective, it also partially coincides with the zoogeographic Pampean Dominion, an ecotonal area that has suffered constant environmental changes during the Quaternary, acquiring Patagonian and Brazilian characteristics alternatively (Ringuelet 1961). In addition, during the last centuries, environmental changes have been intensified by human activities, gradually transforming the natural Pampean grasslands into a mosaic of agroecosystems (León and Burkart 1998), resulting in substantial changes in the taxonomic structure of the small mammal assemblages inhabiting this area (Pardiñas et al. 2010; Teta et al. 2010).

Small mammal assemblages from this area have been mainly studied through the use of trapping techniques or from material recovered from owl pellets (e.g. Reig 1964; Massoia and Fornes 1965; Contreras 1968; 1973; Massoia 1976; Galliari and Pardiñas 2000; Pardiñas et al. 2004; Leveau et al. 2006). When comparing this fauna with that of other regions of Argentina, the taxonomy and distribution of small mammals in the Pampean Region is one of the best established. In spite of this, recent extensive studies conducted at the Pampas revealed that gaps still exist in the knowledge of the small mammal communities (Pardiñas et al. 2004; 2010; Teta et al. 2010).

In this study, we provide a list of small mammal species recovered from owl pellets collected at 11 locations throughout the Pampean Region. In addition, we report for the first time a large-bodied species of Calomys (sensu Corti et al. 1987) in the Pampean Region, expanding southward the geographic distribution of the large-bodied group of this genus.

\section{MATERIALS AND MethodS}

During the last decade, pellets of barn owls (Tyto alba, Aves, Tytonidae) were collected at 11 locations throughout the Pampean Region (Figure 1 and Appendix I). Studied samples were deposited at the Museo de Historia Natural de San Rafael (MHNSR), Mendoza province, Argentina.

The climate of the Pampean Region is determined by the Atlantic anticyclone, which reduces its effects from northeast to southwest. This results in a heterogeneous climate, which changes gradually from humid in the northeastern area (mean annual precipitation of 1200 $\mathrm{mm}$; mean annual temperature of $18^{\circ} \mathrm{C}$ ) to dry subhumid in the southwestern area (mean annual precipitation of $600 \mathrm{~mm}$; mean annual temperature of $14^{\circ} \mathrm{C}$; Burgos 1968).

The small mammal assemblages studied came from the Pampa (locations 1 to 9) and from the Espinal (locations 10 and 11) phytogeographic provinces. The Pampa is composed by plains and a few isolated mountainous areas; the vegetation is characterized by grasslands, halophytic and psammophytic steppes, reedbeds, and shrublands, dominated by grasses such as Stipa, Aristida, Melica, Briza, Bromus, Eragrostis, and Poa. The Espinal surrounds the Pampa on its northern, western and southern boundaries; the vegetation is characterized by xerophytic forests, savannas and steppes of Prosopis, Acacia, Celtis, Schinus and Geophroea decorticans (Cabrera 1976; León 1991).

From the disaggregated owl pellets, we identified cranial remains to the lowest taxonomic level possible by comparisons with reference collections deposited at Museo de La Plata (MLP) and published literature (e.g. Massoia and Fornes 1965; Massoia 1976; Galliari and Pardiñas 2000). Nevertheless, an open taxonomy was used for Myotis Kaup, 1829; Ctenomys Blainville, 1826 
and Rattus Fischer, 1803; since their fragmentary remains were difficult to indentify to the species level. In addition, Calomys laucha (Fischer, 1814) and Calomys musculinus (Thomas, 1913) are almost indistinguishable from craniodental remains (Pardiñas and Lescano 1995).

For each taxon, we calculated the minimum number of individuals (MNI) by quantifying the most frequent element (maxilla or mandible) from either the right or the left side.

Data on the small mammal assemblage from the location of Olavarría (locality 5) was previously published by Fernández et al. (2009). Nevertheless, when carefully revising the remains named as Calomys cf. C. laucha-C. musculinus by those authors, we realized that a few specimens were morphologically different and larger than the mean body size of the other specimens of Calomys. Therefore, we made morphological and quantitative comparisons between these larger specimens and reference material of species of Calomys that belong to the large-bodied group (see below for this grouping) inhabiting the proximities of the Pampean Region $[C$. callosus (Rengger, 1830), C. callidus (Thomas, 1916), and $C$. venustus (Thomas, 1894)], and the most frequent species of the small-bodied group (C. musculinus) inhabiting the Pampean Region. Collection numbers of Calomys specimens are given in Appendix I.

\section{RESULTS AND DISCUSSION}

Small mammal assemblages are listed in Table 1. A total of 3,421 small mammals were recovered from the pellets of the 11 analyzed samples. Among the 21 identified taxa, the sigmodontine rodent Calomys cf. C. laucha-C. musculinus was the most frequent taxon in almost all locations,

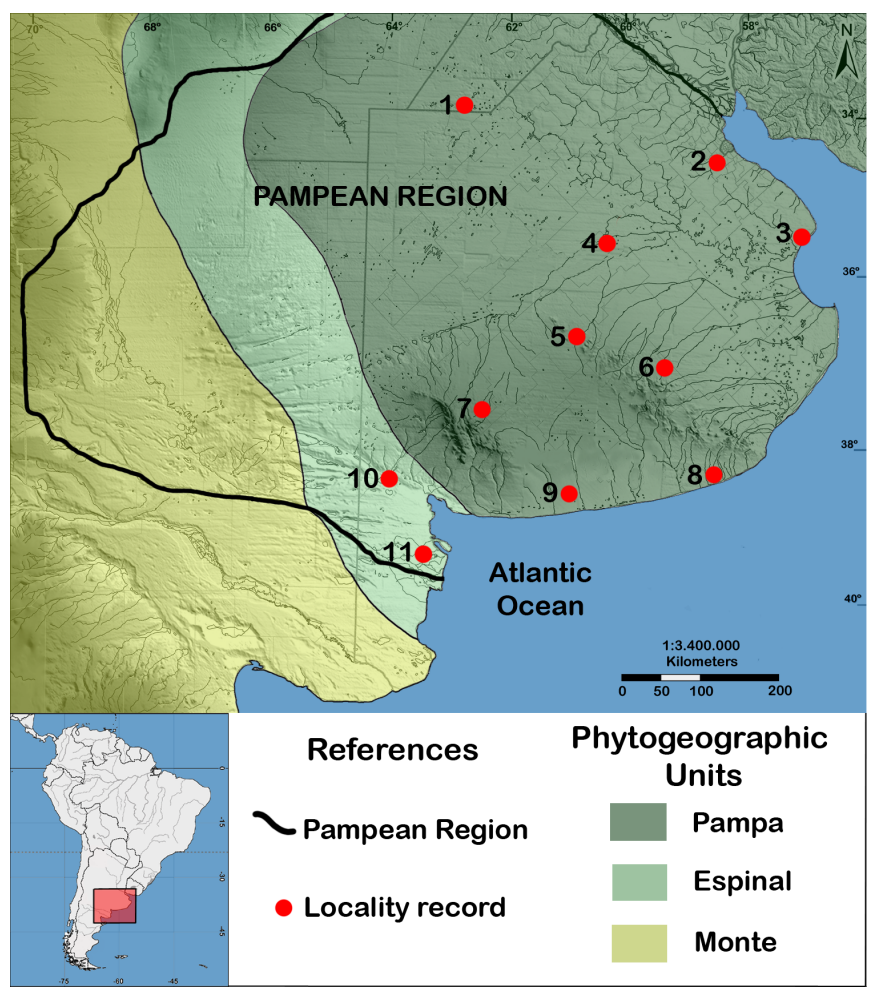

FIGURE 1. Map of the study area, Pampean Region, Argentina. Locations: 1. Diego de Alvear; 2. Tristán Suarez; 3. Pipinas; 4. Saladillo; 5. Olavarría; 6. Tandil; 7. Quiñihual, $8.3 \mathrm{~km} \mathrm{~N}$ of Centinela del mar; 9. Oriente; 10. East coast of Laguna Chasicó; 11. Marahué. Main phytogeographic units according to Cabrera (1976). constituting $63 \%$ of the total specimens, followed by Akodon azarae (Fischer, 1819) and Oligoryzomys flavescens (Waterhouse, 1837) (13.5\% and 10.6\%, respectively). Mus musculus Linnaeus, 1758 constituted $3.3 \%$ of the total sample and was especially abundant in Eastern locations, whereas Eligmodontia typus Cuvier, 1837 constituted 3.2\% of the total specimens identified, being present only in the Espinal (i.e. Laguna Chasicó and Marahué). The remaining small mammals were scarcely represented (e.g. Ctenomys, Myotis, and Thylamys pallidior Thomas, 1902).

The fossil record reveals that recent small mammal assemblages were already established in the Pampean Region during the Pleistocene (Pardiñas et al. 2010). However, at that time, some rodent species, such as $C$. laucha and $C$. musculinus, were much less frequent than they are today. During the last four centuries, especially during the $19^{\text {th }}$ and $20^{\text {th }}$ centuries, the development of agroecosystems would have favoured these species (though increases of population size and extension of their geographic ranges), to the detriment of other populations of rodents, such as Reithrodon auritus (Fischer, 1814) or Necromys lasiurus (Lund, 1840) (see Pardiñas et al. 2010; Teta et al. 2010). Genetic studies of population structure of $C$. laucha and C. musculinus confirm the hypothesis of recent range expansion (e.g. Chiappero et al. 2002; González-Ittig et al. 2007).

Based on ecological and biogeographic characteristics of the species recorded in this study, we can distinguish three main groups of terrestrial small mammals in the Pampean Region. One group is related to the natural grasslands and agroecosystems of the Pampa (Calomys spp., A. azarae, and O. flavescens). Akodon azarae, O. flavescens and C. laucha are distributed from southern Brazil to the southern Pampean Region; whereas C. musculinus has a wider distribution, from Bolivia to southern Patagonia (Pardiñas et al. 2010). The second group comprises Brazilian species [Cavia aperea Erxleben, 1777; Oxymycterus rufus (Fischer, 1814); N. lasiurus; Necromys obscurus (Waterhouse, 1837); Holochilus brasiliensis (Desmarest, 1819) and Monodelphis dimidiata (Wagner, 1847)]. These species present wide distributions, in temperate and humid grasslands, ranging from southern Brazil to the southern Pampean Region, with the exceptions of $N$. obscurus on the one hand, which is restricted to the coast of Uruguay, Buenos Aires Province (Argentina), and hills in the Tandilia System; and C. aperea on the other hand, which presents a wider distribution throughout South America (Redford and Eisenberg 1992; Pardiñas et al. 2010). The third group includes species from Patagonia, Espinal and Monte phytogeographic provinces [T. pallidior; Microcavia australis (I. Geoffroy Saint-Hilaire and d'Orbigny, 1833); Oligoryzomys longicaudatus (Bennett, 1832); E. typus; Graomys griseoflavus (Waterhouse, 1837); Akodon molinae Contreras, 1968]. T. pallidior, M. australis, O. longicaudatus and E. typus are commonly associated with Patagonian and Monte environments, whereas G. griseoflavus and $A$. molinae are mostly restricted to the Espinal and Monte (Redford and Eisenberg 1992; Pardiñas et al. 2010). The exotic murids M. musculus and two species of Rattus [i.e. $R$. rattus (Linnaeus, 1758) and $R$. norvegicus (Berkenhout, 1769)], commonly associated with human settlements, could be regarded as an additional group. 
TABLE 1. Minimum number of individuals (MNI) of small mammals recovered from pellets of Tyto alba collected at 11 locations in the Pampean Region, Argentina: 1. Diego de Alvear; 2. Tristán Suarez; 3. Pipinas; 4. Saladillo; 5. Olavarría; 6. Tandil; 7. Quiñihual; 8.3 km N of Centinela del Mar; 9. Oriente; 10. East coast of Laguna Chasicó; 11. Marahué.

\begin{tabular}{|c|c|c|c|c|c|c|c|c|c|c|c|}
\hline & 1 & 2 & 3 & 4 & 5 & 6 & 7 & 8 & 9 & 10 & 11 \\
\hline \multicolumn{12}{|l|}{ MAMMALIA } \\
\hline \multicolumn{12}{|l|}{ DIDELPHIMORPHIA } \\
\hline Monodelphis dimidiata & & & & & & 1 & 1 & & & & \\
\hline Thylamys pallidior & & & & & & 3 & 1 & & & & \\
\hline \multicolumn{12}{|l|}{ CHIROPTERA } \\
\hline \multicolumn{12}{|l|}{ Vespertilionidae } \\
\hline Myotis sp. & & & & 1 & & & 1 & & & & 5 \\
\hline \multicolumn{12}{|l|}{ RodENTIA } \\
\hline \multicolumn{12}{|l|}{ Ctenomyidae } \\
\hline Ctenomys sp. & & & 16 & & & & & & 1 & 7 & \\
\hline \multicolumn{12}{|l|}{ Caviidae } \\
\hline Cavia aperea & & 3 & & & & & 2 & & & & \\
\hline Microcavia australis & & & & & & & & & 1 & & 1 \\
\hline \multicolumn{12}{|l|}{ Cricetidae } \\
\hline Akodon azarae & 10 & 43 & 66 & 81 & 15 & 57 & 47 & 88 & 15 & 11 & 28 \\
\hline Akodon molinae & & & & & & & & & & 1 & 3 \\
\hline Necromys lasiurus & & & & & & 14 & 2 & & & & \\
\hline Necromys obscurus & & & & & & & & 6 & & & \\
\hline Oxymycterus rufus & & & & & & 43 & 4 & 3 & & & \\
\hline Oligoryzomys flavescens & 46 & 47 & 50 & 73 & 17 & 51 & 27 & 40 & 8 & 2 & \\
\hline Oligoryzomys longicaudatus & & & & & & & & & & & 20 \\
\hline Holochilus brasiliensis & & & & & 1 & 2 & 2 & & & & \\
\hline Calomys cf. C. laucha-C. musculinus & 113 & 21 & 42 & 158 & 46 & 62 & 538 & 122 & 799 & 56 & 197 \\
\hline Calomys sp. & & & & & 4 & & & & & & \\
\hline Eligmodontia typus & & & & & & & & & & 51 & 59 \\
\hline Graomys griseoflavus & & & & & & & & & & 1 & 6 \\
\hline Reithrodon auritus & & 1 & 2 & & & 2 & 34 & 2 & 14 & 1 & \\
\hline \multicolumn{12}{|l|}{ Muridae } \\
\hline Mus musculus & & & & & 5 & 7 & 15 & 13 & 69 & & 3 \\
\hline Rattus sp. & & & & 1 & 6 & 1 & 2 & & 1 & & \\
\hline Total & 169 & 115 & 176 & 314 & 94 & 243 & 676 & 274 & 908 & 130 & 322 \\
\hline
\end{tabular}

TABLE 2. Descriptive statistics of craniodental measurements of large-bodied Calomys from Olavarría and selected samples of $C$. venustus, $C$. callosus, $C$. callidus, and C. musculinus. Sample size in parentheses, mean \pm SD, and range of variation. Measurements are in mm. ${ }^{*}$ Data from Bonvicino et al. (2010: Table 3).

\begin{tabular}{|c|c|c|c|c|c|c|c|}
\hline & Rostral width & $\begin{array}{l}\text { Interorbital } \\
\text { constriction }\end{array}$ & Palatal lenght & Palatal width & $\begin{array}{c}\text { Incisive foramina } \\
\text { lenght }\end{array}$ & $\begin{array}{c}\text { Maxillary toothrow } \\
\text { lenght }\end{array}$ & $\begin{array}{c}\text { Upper diastema } \\
\text { lenght }\end{array}$ \\
\hline Calomys sp. & $4.87 \pm 0.28$ & $4.42 \pm 0.25$ & $11.64 \pm 0.15$ & $2.42 \pm 0.23$ & $5.97 \pm 0.30$ & $4.33 \pm 0.20$ & $6.67 \pm 0.30$ \\
\hline (4) & $4.46-5.07$ & $4.20-4.77$ & $11.48-11.83$ & $2.19-2.69$ & $5.64-6.29$ & $4.19-4.63$ & $6.32-7.03$ \\
\hline C. venustus & $5.13 \pm 0.31$ & $4.37 \pm 0.19$ & $12.29 \pm 0.58$ & $2.93 \pm 0.17$ & $5.92 \pm 0.28$ & $4.81 \pm 0.35$ & $6.67 \pm 0.44$ \\
\hline$(10)$ & $4.64-5.60$ & $4.13-4.65$ & $11.46-13.32$ & $2.63-3.13$ & $5.43-6.28$ & $4.44-5.44$ & $6.29-7.57$ \\
\hline C. callosus & $4.91 \pm 0.46$ & $4.19 \pm 0.36$ & $11.60 \pm 0.74$ & $2.86 \pm 0.29$ & $5.89 \pm 0.47$ & $4.35 \pm 0.25$ & $6.75 \pm 0.56$ \\
\hline $\begin{array}{l}\text { C. callidus* } \\
\text { (11) }\end{array}$ & $\begin{array}{c}5.2 \\
4.8-5.6\end{array}$ & $\begin{array}{c}4.6 \\
4.3-5.0\end{array}$ & - & - & $\begin{array}{c}5.9 \\
5.3-6.4\end{array}$ & $\begin{array}{c}4.1 \\
3.8-4.4\end{array}$ & $\begin{array}{c}6.6 \\
4.7-7.1\end{array}$ \\
\hline C. musculinus & $3.32 \pm 0.37$ & $3.48 \pm 0.09$ & $7.96 \pm 0.62$ & $2.35 \pm 0.15$ & $4.04 \pm 0.41$ & $3.34 \pm 0.16$ & $4.84 \pm 0.40$ \\
\hline (11) & $2.40-3.74$ & $3.39-3.69$ & $6.74-8.89$ & $2.13-2.63$ & $3.31-4.66$ & $3.15-3.57$ & $4.34-5.67$ \\
\hline
\end{tabular}

Some species of small mammals recorded by previous surveys in the Pampean Region (e.g. Pardiñas et al. 2010; Teta et al. 2010) were not recorded in this study. These include, for example, species restricted to the northeastern area and belonging to the second (Brazilian) group [e.g. Holochilus chacarius Thomas, 1906; Oligoryzomys nigripes (Olfers, 1818); Scapteromys aquaticus Thomas, 1920; Bibimys torresi Massoia, 1979; and Deltamys kempi Thomas, 1917], and species belonging to the above-mentioned third group (e.g. Akodon iniscatus Thomas, 1906; and Phyllotis xanthopygus bonariensis Crespo, 1964).
As mentioned above, few specimens of the genus Calomys from Olavarría were larger and morphologically different from those determined as Calomys cf. $C$. laucha-C. musculinus (Table 2 and Figure 2). Some authors informally grouped the species of Calomys by their size into two groups: small- and large-bodied size [e.g. Corti et al. (1987); see external measurements of some of the species of these two groups in Bonvicino et al. (2010: Table 3)]. In fact, molecular phylogenies show the existence of two natural groups: highland and lowland Calomys (e.g. Salazar-Bravo et al. 2001; Almeida et al. 2007). In 
addition, these studies also supported a monophyletic clade containing all large-bodied species within the lowland Calomys group. Among the species of this largebodied clade, only $C$. venustus has been registered in the northwestern Pampean Region, whereas C. callosus and C. callidus have a distribution that reaches the northern boundaries of this region. The taxonomy of these three species is controversial. Hershkovitz (1962) considered $C$. venustus and $C$. callidus as synonyms of $C$. callosus. Later studies based on morphometric, cytogenetic and molecular data have supported the validity of these species (e.g. Corti et al. 1987; Salazar-Bravo et al. 2001; 2002). Nevertheless, Contreras et al. (2003) on the basis of cytogenetic data and the relocation of the type locality of $C$. callosus (outside the range of its geographic distribution), stated that this species and $C$. callidus should be considered as conspecific.

In this context, we observed that the large specimens from Olavarría presented some morphological characteristics shared with species of the large-bodied group of Calomys. These include prominent lateral and divergent borders of the frontals, and parallel maxillary toothrows (Figure 2). On the contrary, smoother and less divergent borders of the frontals, and convergent maxillary toothrows are features of the small-bodied species of the genus registered in Buenos Aires Province to date $(C$. laucha and C. musculinus). The larger Calomys specimens from Olavarría also differed in other characteristics from the species of the large-bodied group (C. venustus, $C$. callidus, C. callosus): posteropalatal pits deeper (except when comparing with $C$. venustus); anterior border of the mesopterygoid fossa more attenuated $M$ shape; zygomatic notch shallower and narrower; anterior border of the zygomatic plate nearly straight, as in all large-bodied species (with the exception of $C$. venustus, in which it is convex in its upper part). The craniodental measurements of the specimens of Calomys studied here are given in Table 2. Measurements of the specimens from Olavarría were within the range of those of the large-bodied group of Calomys and larger than those of $C$. musculinus, with the exception of palatal width.

The species of the large-bodied group of Calomys present a geographic distribution from the lowlands at central and southeastern Brazil, Paraguay and Bolivia to southern Córdoba, Santa Fe and Entre Ríos Provinces in Argentina. These species inhabit warm environments of the Chaco, Espinal, dry forests, savannas, and pampas (Contreras et al. 2003; Almeida et al. 2007; Bonvicino et al. 2010). Therefore, the material described here constitutes the first record of the large-bodied group of Calomys in Buenos Aires Province, expanding the known distribution of this group ca. $420 \mathrm{~km}$ southward. Despite the lack of an

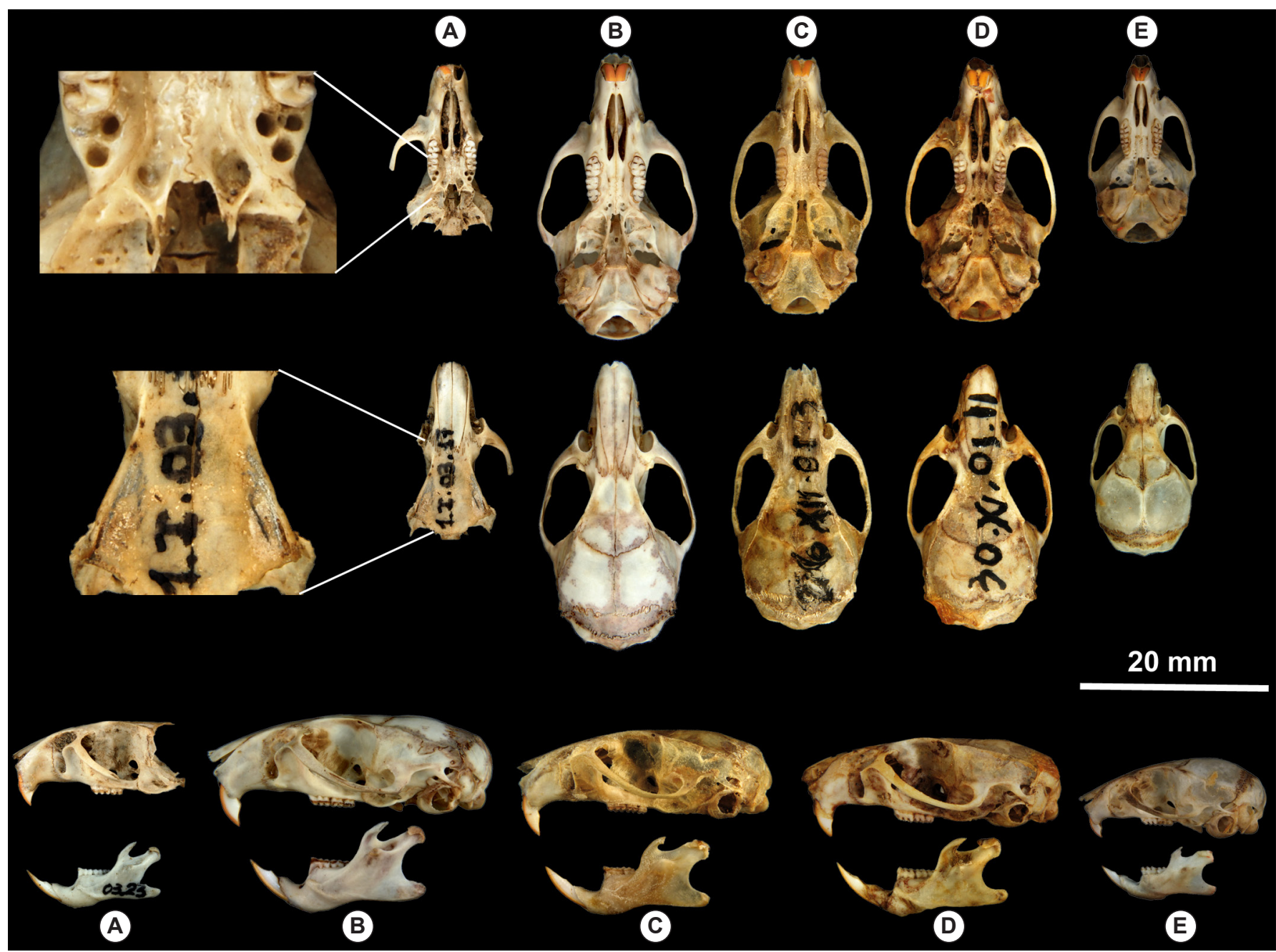

FIGURE 2. Skulls and mandibles of large-bodied Calomys from Olavarría and reference species. A. Calomys sp. (MLP 1.I.03.17, MLP-1.I.03.23); B. C. venustus (MLP 31. XII. 02. 68); C. C. callidus (MLP 26. XII. 01. 3); D. C. callosus (MLP 30. XI. 01. 11) and E. C. musculinus (MLP 31. XII. 02. 07). Above: ventral view; middle: dorsal view; bellow: lateral view. Detailed views of Calomys sp. from Olavarria show morphological characters described in the text. 
accurate identification of these remains, we do not discard the hypothesis that these specimens belong to a distinct species, possibly endemic to central Buenos Aires province. Future trapping efforts in the vicinity of Olavarría can shed light on their taxonomic status.

Our dataset shares similarities to previous studies in the Pampean Region. Nevertheless, the record of a species of Calomys of the large-bodied group in the center of this area points to the existence of gaps in our knowledge on the small mammal fauna of this region.

Acknowledgments: We thank Damian Miguelisi, Luciano Rei, and Mario Silveira for providing us with two pellet samples of Tyto alba. Pablo Teta provided some of the Calomys material used in comparisons. We appreciate Pablo Teta and Ulyses Pardiñas for their useful comments and discussion on the taxonomy of Calomys. This work was funded by UNLP (Project 11/N601). F. Fernández and F. Idoeta were supported by fellowships from CONICET (Consejo Nacional de Investigaciones Científicas y Técnicas); G. Moreira and F. Ballejo were supported by CIC (Comisión de Investigaciones de la Provincia de Buenos Aires).

\section{Literature Cited}

Almeida, F.C., C.R. Bonvicino and P. Cordeiro-Estrela. 2007. Phylogeny and temporal diversification of Calomys (Rodentia, Sigmodontinae): Implications for the biogeography of an endemic genus of the open/ dry biomes of South America. Molecular Phylogenetics and Evolution 42(2): 449-466

Bonvicino, C.R., J.A. De Oliveira and R. Gentile. 2010. A new species of Calomys (Rodentia: Sigmodontinae) from Eastern Brazil. Zootaxa 2336: 19-25.

Barquez, R.M., M.A. Mares and J.K. Braun. 1999. The bats of Argentina. Texas: Special Publications 42, Museum of Texas Tech University. 274 p.

Burgos, J.J. 1968. Los climas de la provincia de Buenos Aires en relación con la vegetación natural y el suelo; p. 33-99 In A.L. Cabrera (ed.). Flora de la provincia de Buenos Aires. Volume IV. Buenos Aires: Colección Científica, Instituto Nacional de Tecnología Agropecuaria.

Cabrera, A.L. 1976. Regiones fitogeográficas argentinas. Enciclopedia Argentina de Agricultura y Jardinería 2(1): 1-85.

Chiappero, M.B., A. Blanco, G.E. Caldero, M.S. Sabattini and C.N. Gardenal. 2002. Genetic structure of populations of Calomys laucha (muridae, sigmodontinae) from central Argentina. Biochemical Systematics and Ecology 30: 1023-1036.

Contreras, J.R. 1968. Akodon molinae es una especie de ratón de campo del sur de la provincia de Buenos Aires. Zoología Platense, Investigaciones zoológicas y paleontológicas 1(2): 9-12.

Contreras, J.R. 1973. La mastofauna de la zona de la Laguna Chasicó, provincia de Buenos Aires. Physis, Sección C 32(84): 215-219.

Contreras, J.R., P. Teta and A. Andrade. 2003. Comentarios sobre el estatus de Calomys callosus (Rengger) y nuevos datos sobre la distribución de micromamíferos en el noroeste de la provincia de Corrientes (Argentina). Revista del Museo Argentino de Ciencias Naturales 5(1): 73-78.

Corti, M., M.S. Merani and G. Villafane. 1987. Multivariate morphometrics of vesper mice (Calomys): preliminary assessment of species, population, and strain divergence. Zeitschrift für Säugetierkunde 52(1): 236-242.

Fernández, F.J., G. Moreira, D. Ferraro and L. De Santis. 2009. Presas consumidas por la lechuza de campanario (Tyto alba) en la localidad de Olavarría, Buenos Aires: un caso de elevada batracofagia. Nuestras Aves 54(1): 20-21.

Galliari, C.A. and U.F.J. Pardiñas. 2000. Taxonomy and distribution of the sigmodontinae rodents of genus Necromys in central Argentina and Uruguay. Acta Theriologica 45(2): 211-232.

González-Ittig, R.E., J.L. Patton and C.N. Cardenal. 2007. Analysis of cytochrome-b nucleotide diversity confirms a recent range expansion in Calomys musculinus (Rodentia, Muridae). Journal of Mammalogy 88 (3): 777-783.

Hershkovitz, P. 1962. Evolution of Neotropical cricetine rodents (Muridae) with special reference to the phyllotine group. Fieldiana: Zoology 46(1): 1-524.

León, R.J.C. 1991. Geographic limits of the region, geomorphology and geology, Regional subdivisions, Floristic aspects, Description of the vegetation; p. 369-387 In R.T. Coupland (ed.). Natural Grasslands: Introduction and Western Hemisphere. Amsterdam: Elsevier.

León, R.J.C. and S.E. Burkart. 1998. El pastizal de la Pampa deprimida: estados alternativos. Ecotropicos 11(2): 121-130.
Leveau, L.M., P. Teta, R. Bogdaschewsky and U.F.J. Pardiñas. 2006. Feeding habits of the barn owl (Tyto alba) along a longitudinal-latitudinal gradient in Central Argentina. Ornitología Neotropical 17(3): 353362.

Massoia, E. 1976. Mammalia; p. 1-128 In R. Ringuelet (ed.). Fauna de Agua Dulce de la República Argentina. Buenos Aires: Fundación Editorial Ciencia y Cultura.

Massoia, E. and A. Fornes. 1965. Contribución al conocimiento de los roedores miomorfos argentinos vinculados con la fiebre hemorrágica argentina. Buenos Aires: Ministerios de Asuntos Sociales y Salud Pública de la Nación, Difusión de la Comisión Nacional Coordinadora para el Estudio y Lucha contra la Fiebre Hemorrágica Argentina. 24 p.

Pardiñas, U.F.J. and M.J. Lescano. 1995. Cricétidos (Mammalia, Rodentia) del Pleistoceno tardío del nordeste de la provincia de Buenos Aires (Argentina). Aspectos sistemáticos y paleoambientales. Ameghiniana 32 (3): 249-265.

Pardiñas, U.F.J., A.M. Abba and M.L. Merino. 2004. Micromamíferos (Didelphimorphia y Rodentia) del sudoeste de la provincia de Buenos Aires (Argentina): taxonomía alfa y distribución. Mastozoología Neotropical 11(2): 211-232.

Pardiñas, U.F.J., P. Teta and G. D’Elía. 2010. Roedores sigmodontinos de la región pampeana: Historia evolutiva, sistemática y taxonomía; p. 9-36 In J.J. Polop and M. Busch (ed.). Biología y Ecología de pequeños roedores en la región pampeana de Argentina. Córdoba: Universidad Nacional de Córdoba.

Redford, K.H. and J.F. Eisenberg. 1992. Mammals of the Neotropics. The Southern Cone. Chicago and London. Chicago: The Universtiy of Chicago Press. 430 p.

Reig, O.A. 1964. Roedores y marsupiales del partido de General Pueyrredón y regiones adyacentes (provincia de Buenos Aires, Argentina). Publicaciones del Museo Municipal de Ciencias Naturales de Mar del Plata 1(6): 203-224.

Ringuelet, R.A. 1961. Rasgos fundamentales de la zoogeografía de la Argentina. Physis 22 (63): 151-170.

Salazar-Bravo, J., J.W. Dragoo, S.D.Tinnin and T.L. Yates. 2001. Phylogeny and Evolution of the Neotropical Rodent Genus Calomys: Inferences from Mitochondrial DNA Sequence Data. Molecular Phylogenetics and Evolution 20(2): 173-184.

Salazar-Bravo, J., J.W. Dragoo, M.D. Bowen, C.J. Peters, T.G. Ksiazek and T.L. Yates. 2002. Natural nidality in Brazilian hemorragic fever and the systematic of the reservoir species. Infection, Genetics and Evolution 1: 191-199.

Teta, P., C.M. Gonzáles-Fischer, M. Codecido and D.N. Bilenca. 2010. A contribution from Barn Owl Pellets analisys to known micromammalian distributions in Buenos Aires province, Argentina. Mammalia 74(1): 97-103.

RECEIVED: October 2011

ACCEPTED: February 2012

PuBlished ONLINE: February 2012

EDITORIAL RESPONSIBILITY: Ana Paula Carmignotto

\section{APPEndix 1. Samples examined.}

1. Diego de Alvear $\left(34^{\circ} 22^{\prime} \mathrm{S}, 62^{\circ} 07^{\prime} \mathrm{W}\right)$, General López, Santa Fé:

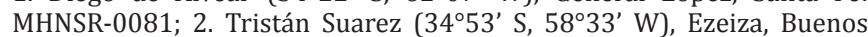
Aires: MHNSR-0082 ; 3. Pipinas ( $\left.35^{\circ} 32^{\prime} \mathrm{S}, 5^{\circ} 13^{\prime} \mathrm{W}\right)$, Punta Indio, Buenos

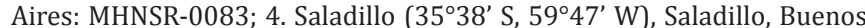
Aires: MHNSR-0084; 5. Olavarría (3653' S, 60¹8’ W), Olavarría, Buenos

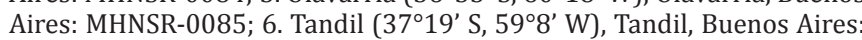

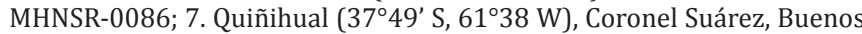
Aires: MHNSR-0087; $8.3 \mathrm{~km} \mathrm{~N}$ of Centinela del mar $\left(38^{\circ} 25^{\prime} \mathrm{S}, 58^{\circ} 12^{\prime}\right.$ W), General Alvarado, Buenos Aires: MHNSR-0088; 9. Oriente (38 ${ }^{\circ} 44^{\prime}$ S, 60³6' W), Coronel Dorrego, Buenos Aires: MHNSR-0089; 10. East

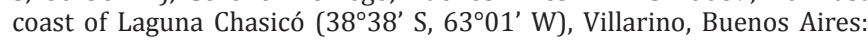
MHNSR-0090; and 11. Marahué (39 $32^{\prime}$ S, $62^{\circ} 25^{\prime} \mathrm{W}$ ), Villarino, Buenos Aires: MHNSR-0091.

Calomys sp., Olavarría (3653' S, 60¹8’ W), Olavarría, Buenos Aires. Skulls: MLP-1.I.03.15; MLP-1.I.03.16; MLP-1.I.03.17; MLP-1994 Mandibles: MLP-1.I.03.18; MLP-1.I.03.19; MLP-1.I.03.20; MLP-1.I.03.21; MLP-1.I.03.22; MLP-1.I.03.23.

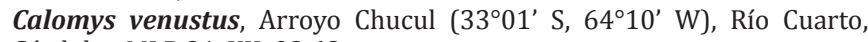
Córdoba: MLP 31. XII. 02.68.

Calomys callidus, Ecia San Juan Poriahu (2742' S, 57ำ1' W), San Miguel, Corrientes: MLP 26. XII. 01.3.

Calomys callosus, Cancha Larga (2632' S, 6058’ W), Almirante Brown, Chaco: MLP 30. XI. 01.11.

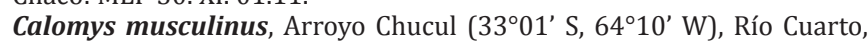
Córdoba: MLP 31. XII. 02.07. 